\title{
GENETIC DIVERGENCE AMONG COWPEA GENOTYPES BASED ON CHARACTERS ASSOCIATED WITH THE GREEN POD AND GRAIN MARKET ${ }^{1}$
}

\author{
JOSÉ TORRES FILHO ${ }^{2 *}$, CHRISTIANE NORONHA GOMES DOS SANTOS OLIVEIRA ${ }^{2}$, LINDOMAR MARIA DA \\ SILVEIRA'2, GLAUBER HENRIQUE DE SOUSA NUNES², CARLA CAROLINE ALVES PEREIRA², ANTÔNIA \\ ELIZIANA AUGUSTA DA SILVA ${ }^{2}$
}

\begin{abstract}
The objective of this study was to evaluate genetic divergence among cowpea genotypes and to select parents for crosses aimed at the fresh pod and grain market. Two experiments were carried out during 2014, corresponding to two sowing times, in the municipality of Mossoró, State of Rio Grande do Norte. Twenty-three cowpea genotypes were evaluated in a randomized complete block design with four replicates. Fifteen descriptors were used to quantify divergence, using the Mahalanobis distance as a measure of dissimilarity, obtained from the genotypic mean predicted by the Restricted Maximum Likelihood/Best Linear Unbiased Prediction (REML/BLUP) method. The Unweighted Pair Group Method with Arithmetic Mean (UPGMA) hierarchical method was used to group genotypes and the Singh criterion to quantify the contribution of traits to genetic divergence. The genotype $\times$ environment interaction $(G \times E)$ influenced divergence, both in the contribution of traits and in the grouping of genotypes. In the experiment 1 , the genotypes were distributed among four groups. In the experiment 2, less discrimination occurred and the genotypes were represented by only two groups. When joint analysis of two evaluations was carried out based on two sowing times, genotypes were represented by six groups. The $\mathrm{G} \times \mathrm{E}$ interaction influences the contribution of traits and the grouping of cowpea genotypes in the study of divergence. The genetic divergence of the set of cowpea genotypes evaluated is mainly due to green grain and pod yield. BRS Aracê and BRS Xiquexique cultivars are the most divergent among the genotypes studied, representing $75 \%$ of the recommended crosses.
\end{abstract}

Keywords: Vigna unguiculata. Genetic distance. Grouping. REML/BLUP.

\section{DIVERGÊNCIA GENÉTICA ENTRE GENÓTIPOS DE FEIJÁO-CAUPI COM BASE EM CARACTERES ASSOCIADOS COM O MERCADO DE VAGENS E GRÃOS VERDES}

\begin{abstract}
RESUMO - O objetivo deste trabalho foi avaliar a divergência genética entre genótipos de feijão-caupi e selecionar genitores para cruzamentos visando o mercado de vagens e grãos verdes. Foram conduzidos dois experimentos, correspondendo a duas épocas de semeadura, no município de Mossoró, Rio Grande do Norte, ano 2014. Foram avaliados 23 genótipos de feijão-caupi em delineamento de blocos casualizados com quatro repetições. Foram utilizados 15 descritores para quantificar a divergência, utilizando como medida de dissimilaridade a distância de Mahalanobis, obtida a partir da média genotípica predita pelo método REML/ BLUP. Utilizou-se o método hierárquico UPGMA para agrupar os genótipos e o critério de Singh para quantificar a contribuição dos caracteres para a divergência genética. A interação genótipos x ambientes influenciou a divergência, tanto na contribuição dos caracteres quanto no agrupamento dos genótipos. Na primeira época de cultivo os genótipos foram distribuídos em quatro grupos. Na segunda época ocorreu menor discriminação, sendo que os genótipos formaram apenas dois grupos. Ao realizar-se o agrupamento com base na análise conjunta das duas avaliações, realizadas nas duas épocas de semeadura os genótipos foram agrupados em seis grupos. A interação genótipos x ambientes influencia a contribuição das características e o agrupamento dos genótipos de feijão-caupi no estudo de divergência. A divergência genética do conjunto de genótipos de feijão-caupi avaliados é devida principalmente a produtividades de grãos verdes e de vagens verdes. As cultivares BRS Aracê e BRS Xiquexique foram os genótipos mais divergentes entre os estudados, fazendo parte de $75 \%$ dos cruzamentos recomendados.
\end{abstract}

Palavras-chave: Vigna unguiculata. Distância genética. Agrupamento. REML/BLUP.

\footnotetext{
${ }^{*}$ Corresponding author

${ }^{1}$ Received for publication in 08/14/2016; accepted in 04/10/2017.

Paper approved from IV CONAC 2016.

Extracted from the second author's Master's dissertation.

${ }^{2}$ Department of Plant Science, Universidade Federal Rural do Semi-Árido, Mossoró, RN, Brazil; torres@ufersa.edu.br, christiane@ufersa.edu.br, lindomarmaria@ufersa.edu.br, glauber@ufersa.edu.br, carlacarolinealves@hotmail.com, liliagro1@hotmail.com.
} 


\section{INTRODUCTION}

The cowpea (Vigna unguiculata L. Walp) is an important food crop which is widely cultivated in several parts of the world and represents an essential component of cropping systems in the driest regions of the tropics (SINGH, 2007). It is a species that possesses the capacity to fix atmospheric nitrogen through its association with bacteria of the genus Rhizobium. It is able to reach high levels of productivity when well nodulated (ALMEIDA et al., 2010; COSTA et al., 2011; SOARES et al., 2006) and is less reliant on good soil fertility compared to other food crops.

In Brazil, cowpea cultivation has an important socioeconomic role, mainly in the North, North-East and Center-West regions. In the North and North-East regions, it represents a staple food for rural populations, as well as providing employment in the field. In the Center-West region, it has been incorporated into production systems such as safrinha or main culture, predominantly in the state of Mato Grosso (FREIRE FILHO, 2011).

The knowledge of the variability present in the germplasm of a culture is carried out after the multiplication, characterization and evaluation of collected accesses. Studies of genetic divergence are usually conducted in only one assessment environment, usually due to resource constraints. However, the phenotype of $\mathrm{G} \times \mathrm{E}$ interaction is common in breeding programs for many crops and has a direct influence on phenotypic manifestation (GAUCH et al., 2008).

$\mathrm{G} \times \mathrm{E}$ interaction is defined as differential behavior between genotypes in different environments and plays a key role in the genotype selection process. It is explained by two components: simple part, due to the magnitude of differences in variability among genotypes; and the complex part, due to the genetic correlation of genotypes in the environments (CRUZ; CASTOLDI, 1991).

The pragmatic consequence of $\mathrm{G} \times \mathrm{E}$ interaction is the difficulty in the selection process of promising genotypes. It has been a common fact in evaluation trials of cowpea cultivars conducted in several Brazilian states (BARROS et al., 2013; FREIRE FILHO et al., 2003, 2005; ROCHA et al., 2007; SANTOS et al., 2008; SANTOS et al., 2016; TEODORO et al., 2015a, b; VALADARES et al., 2010).

Although the existence of $\mathrm{G} \times \mathrm{E}$ interaction is well recognized, there is little information about its influence in studies of divergence. The lack of information requires a closer look from curators and breeders since divergence studies are important in two main respects. The first one is related to the intrinsic activities carried out in germplasm banks in order to evaluate the whole variation structure with the purpose of preserving it and optimizing its maintenance in nuclear collections. The second aspect, no less important than the first one, is that genetic divergence studies are used to define heterotic groups with the intention of directing crosses that could potentially generate segregating populations with greater genetic variability (MIRANDA et al., 2003). In fact, considering that $\mathrm{G} \times \mathrm{E}$ interaction by environments can change the discrimination of accesses in groups according to environmental conditions, the definition of the crossings to be executed can be difficult.

This work aimed at studying genetic divergence among cowpea genotypes and the selection of parental crosses suitable for the marketing of green pods and grains.

\section{MATERIAL AND METHODS}

Twenty-three cowpea genotypes, comprising cultivars and lineages developed by Embrapa Meio-Norte and local cultivars from different Brazilian states, were evaluated (Table 1).

Two experiments were carried out at the Experimental Garden of the Department of Plant Sciences (DPS) at the Federal Rural University of Semi-Arid (FRUSA), Campus Mossoró, RN, located at $5^{\circ} 11^{\prime} \mathrm{S}$ latitude, $37^{\circ} 20^{\prime} \mathrm{W}$ longitude and $18 \mathrm{~m}$ altitude. The climate, according to Köppen's classification, is 'BShW', namely dry and very hot, with a dry climatic season (June to January) and a rainy season (February to May). The temperature is 21.3-34.5 ${ }^{\circ} \mathrm{C}$. The average annual rainfall is around $625 \mathrm{~mm}$ (CARMO FILHO; ESPINOLA SOBRINHO; MAIA NETO, 1991). The soil in the experimental area was classified as Ultisol (EMBRAPA, 1999). The experiments were conducted during the periods March 23 to May 17 (Experiment 1) and August 13 to October 24 (Experiment 2), 2014. Soil preparation consisted of plowing and harrowing at depth of $0.30 \mathrm{~m}$. Prior to planting, soil samples were collected from the area for fertility analysis, which was carried out at the Plant Nutrition Laboratory of the Plant Research Center of the Semi-Arid at the DPS. The following results were obtained from soil samples: experiment $1\left(\mathrm{pH}=5.8 ; \mathrm{EC}=181.4 \mu \mathrm{s} \mathrm{m}^{-1} ; \mathrm{P}=13.9 \mathrm{mg} \mathrm{dm}^{-3}\right.$ and $\left.\mathrm{K}=150.1 \mathrm{mg} \mathrm{dm}^{-3}\right)$; experiment $2(\mathrm{pH}=7.7$, $\mathrm{EC}=179.5 \mu \mathrm{s} \mathrm{m}^{-1}, \mathrm{P}=14.0 \mathrm{mg} \mathrm{dm}^{-3}$ and $\left.\mathrm{K}=182.25 \mathrm{~g} \mathrm{dm}^{-3}\right)$.

The experimental design involved a randomized complete block with 23 treatments and four replications. The plot was composed of five rows of $5.00 \mathrm{~m}$, spaced $0.80 \mathrm{~m}$ apart. The spacing between holes was $0.25 \mathrm{~m}$, with two plants per hole. The harvest plot consisted of the two central rows. No fertilization was carried out. During the two growing seasons, a drip irrigation system was used, with an average flow rate of $1.52 \mathrm{l} / \mathrm{h}$. The Christiansen coefficient of uniformity was $100 \%$ and the distribution coefficient was $94.6 \%$. 
Table 1. Cowpea genotypes evaluated for green bean production.

\begin{tabular}{|c|c|c|}
\hline Treatments & Genotypes & Genotype types \\
\hline 1 & MNC00-586F-303-9 & Line \\
\hline 2 & MNC00-595F-2 & Line \\
\hline 3 & MNC00-595F-27 & Line \\
\hline 4 & MNC05-835B-15 & Line \\
\hline 5 & MNC05-835-B-16 & Line \\
\hline 6 & MNC05-841-B-49 & Line \\
\hline 7 & MNC05-847B-123 & Line \\
\hline 8 & MNC05-847B-126 & Line \\
\hline 9 & MNC99-541F-15 & Line \\
\hline 10 & BRS Guariba & Cultivar \\
\hline 11 & BRS Tumucumaque & Cultivar \\
\hline 12 & BRS Xiquexique & Cultivar \\
\hline 13 & Paulistinha ${ }^{1}$ & Cultivar \\
\hline 14 & Vagem Roxa-THE ${ }^{2}$ & Cultivar \\
\hline 15 & Azulão-MS ${ }^{3}$ & Cultivar \\
\hline 16 & Sempre-Verde-CE ${ }^{1}$ & Cultivar \\
\hline 17 & BRS Aracê & Cultivar \\
\hline 18 & Pingo-de-ouro-1-2 ${ }^{1}$ & Cultivar \\
\hline 19 & MNC02-701F-2 & Line \\
\hline 20 & MNC99-510f-16-1 & Line \\
\hline 21 & São Miguel ${ }^{4}$ & Cultivar \\
\hline 22 & Filipe Guerra ${ }^{4}$ & Cultivar \\
\hline 23 & Sd Matos ${ }^{4}$ & Cultivar \\
\hline
\end{tabular}

The following morpho-agronomic descriptors were evaluated: number of days for flowering (NDF); percentage of lodging (PL); number of days for maturation (NDM); plant height (PH); length of pod, in cm (LP); number of grains per pod (NGP); weight of pod, in g (WP); weight of grains, in $\mathrm{g}$ (WG); index of green grains, in \% (IGG); yield of green grains, in $\mathrm{kg} \mathrm{ha}^{-1}$ (YGG); yield of green pods, in $\mathrm{kg} \mathrm{ha}^{-1}$ (YGP); hydrogen-ionic potential $(\mathrm{pH})$; soluble solids (SS), ${ }^{\circ}$ Brix; chlorophyll (CHL), and total carotenoids (TC).

To evaluate the effect of the $\mathrm{G} \times \mathrm{A}$ interaction via REML/BLUP, we used the SELEGEN-REML/ BLUP software model 54 (RESENDE, 2007). This is represented by $\mathrm{y}=\mathrm{Xb}+\mathrm{Zg}+\mathrm{Wc}+\mathrm{e}$, where $\mathrm{y}, \mathrm{b}, \mathrm{g}$, $\mathrm{c}$ and $\mathrm{e}$ are fixed-effect data vectors (block means across environments), genotype effects (random), genotype $\times$ environment (random) interaction effects and random errors, respectively. $\mathrm{X}, \mathrm{Z}$ and $\mathrm{W}$ are incidence matrices for $\mathrm{b}, \mathrm{g}$ and $\mathrm{c}$, respectively.

With the genotypic means, also using the software SELEGEN-REML/BLUP, genetic correlations between the evaluated characteristics were determined. Multivariate analysis was performed to estimate genetic divergence between the characteristics based on genotypic values and involved dissimilarity measures using the generalized distance of Mahalanobis (D2) (MAHALANOBIS, 1936) and subsequent grouping of individuals in similarity groups using the UPGMA method. Model 104 of the SELEGEN-REML/BLUP computer program was used to determine the generalized distance of Mahalanobis.

The quality of the adjustment was quantified by the cophenetic correlation coefficient (SOKAL; ROHLF, 1962). The criterion of Singh (1981) was used to determine the relative contribution of each trait to genetic divergence. These analyses were performed using the GENES program, Computational Application in Genetics and Statistics (CRUZ, 2013). In order to establish the number of divergent groupings by means of the cut-off point, the procedure proposed by Mojena (1977) was used, based on the relative size of merging (distances) levels in the dendrogram. These analyses were also performed using the GENES program.

\section{RESULTS AND DISCUSSION}

The application of the UPGMA method from the Mahalanobis distances matrix $\left(D^{2}\right)$ enabled distribution of the genotypes studied into four groups in the experiment 1 (Figure 1). The first group was formed by the lineages MNC00-586F-303-9, MNC05-847B-126 and MNC99-510F-16-1 and the cultivar Filipe Guerra. Group II was composed of the genotypes MNC00-595F-2, 
Sempre Verde-CE, MNC00-595F-27, Sd Matos, BRS Tumucumaque, MNC05-835B-15, MNC05-835B-16, MNC05-847B-123, MNC05841B-49, BRS Aracê and Azulão-MS. The largest group consisted of 11 genotypes $(52.17 \%)$. The third group consisted of genotypes MNC99-541F-15, MNC02-701F-2, BRS Guariba, Vagem Roxa-THE, Pingo-de-ouro-1-2 and São Miguel. Group IV was composed only of the cultivar BRS Xiquexique.

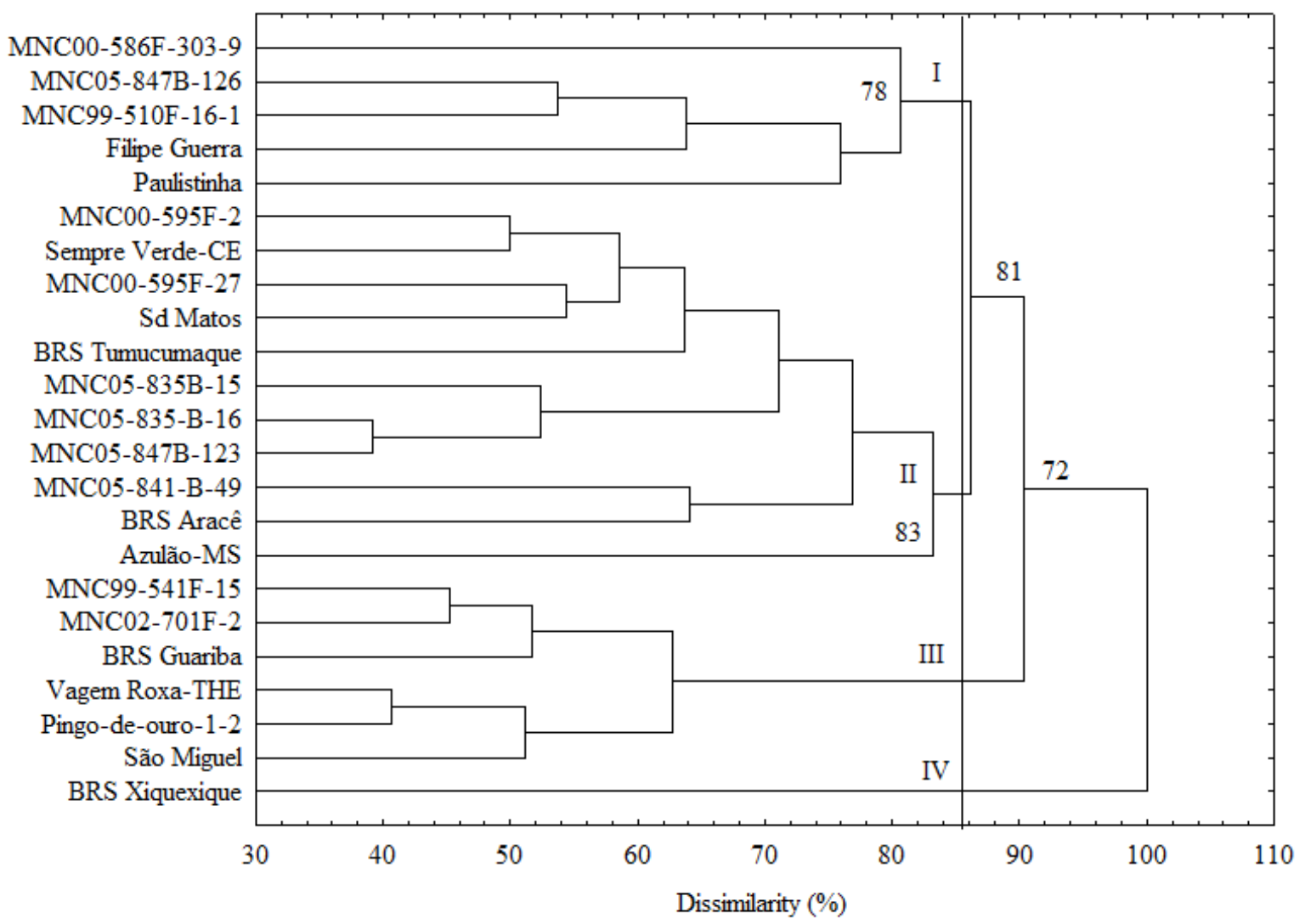

Figure 1. UPGMA grouping of cowpea genotypes evaluated in Experiment 1 from the distances of Mahalanobis. (Cophenetic correlation $\mathrm{r}_{1}=0.76^{* *}, \mathrm{p}<0.01$ ).

In the second evaluation (experiment 2), there was less discrimination since the genotypes were allocated to two groups only (Figure 2). Group two was composed of the genotypes BRS Tumucumaque, Sempre Verde-CE, São Miguel and Azulão-MS. The first group was composed of the remaining genotypes that were evaluated.

Grouping of genotypes was also carried out based on joint analysis of two evaluations, carried out in the two sowing seasons. At this time, the genotypes were grouped into six groups (Figure 3). Notwithstanding the differences observed in the groups formed between the two analyses (experiments) of grouping, consistencies were observed in the grouping process. The cultivars Azulão-MS, MNC05-847B-123, BRS Xiquexique and BRS Aracê were grouped in isolation. The second group was composed of genotypes BRS Guariba, São Miguel, MNC02-701F-2, Vagem Roxa-THE, Pingo-de-ouro-1-2 and MNC99-541F-15, while the first group consisted of the other genotypes. The UPGMA method was also efficient for grouping genotypes based on joint analysis of data.

It should be noted that groupings performed by the UPGMA method were efficient for both individual analyses and for joint analysis, since the estimates of the cophenetic correlation coefficients were greater than 0.76 . The consensus branching index and the correlation between genetic distance matrices were used to verify the similarity of constructed dendrograms (Table 2). The consensus branching index observed among the dendrograms generated in the individual evaluations was $27.118 \%$ and the matrix correlation was $0.34 *$, showing that classification of genotypes was distinct in both evaluations. On the other hand, the estimates of matrix correlation between the joint evaluation and the two individual evaluations were 0.83 and 0.52 , while the consensus indices among the dendrograms were 64.32 and 41.26 , respectively. 


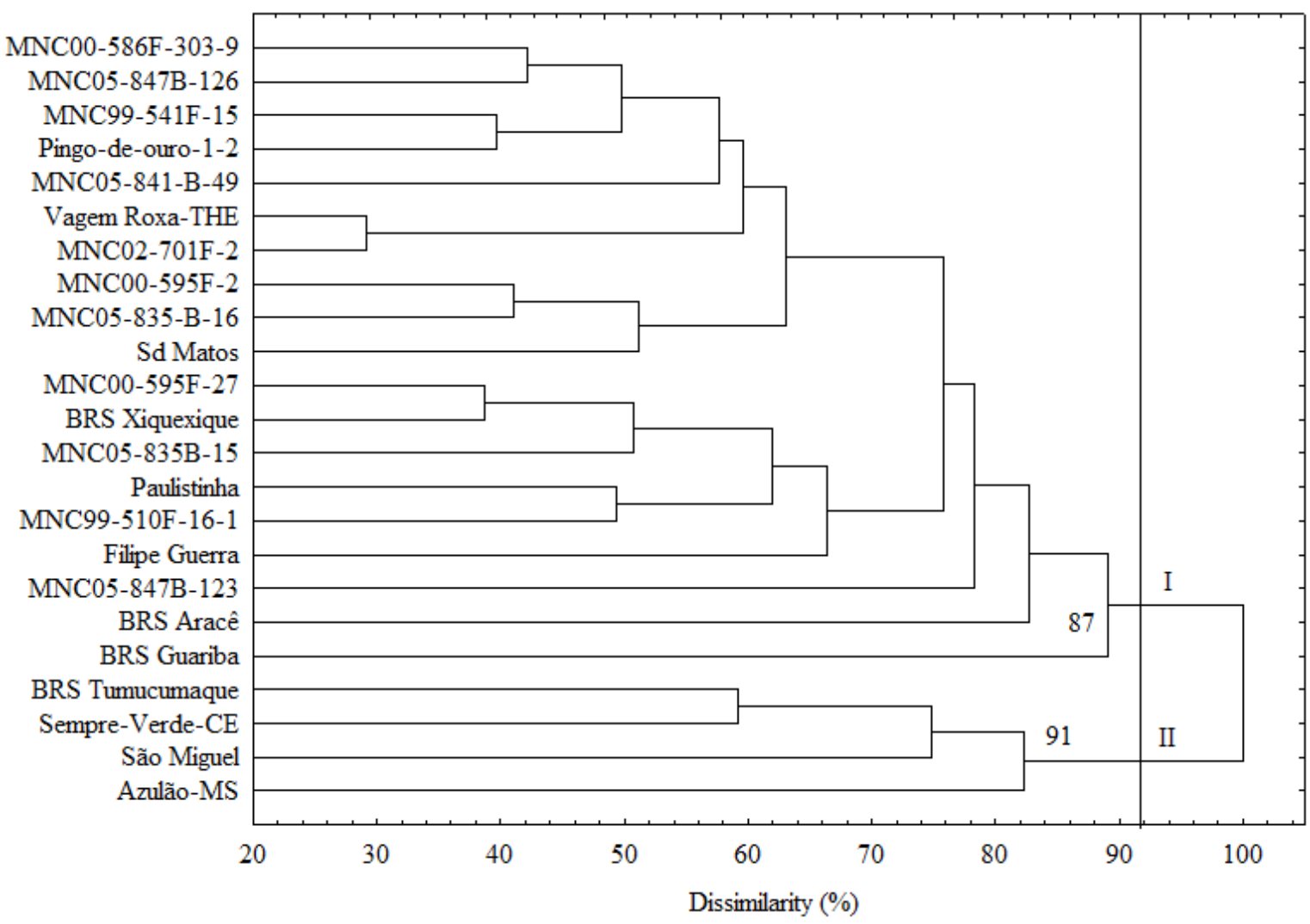

Figure 2. UPGMA grouping of cowpea genotypes evaluated in Experiment 2 from the distances of Mahalanobis. (Cophenetic correlation $\mathrm{r} 1=0.78^{* *}, \mathrm{p}<0.01$ ).

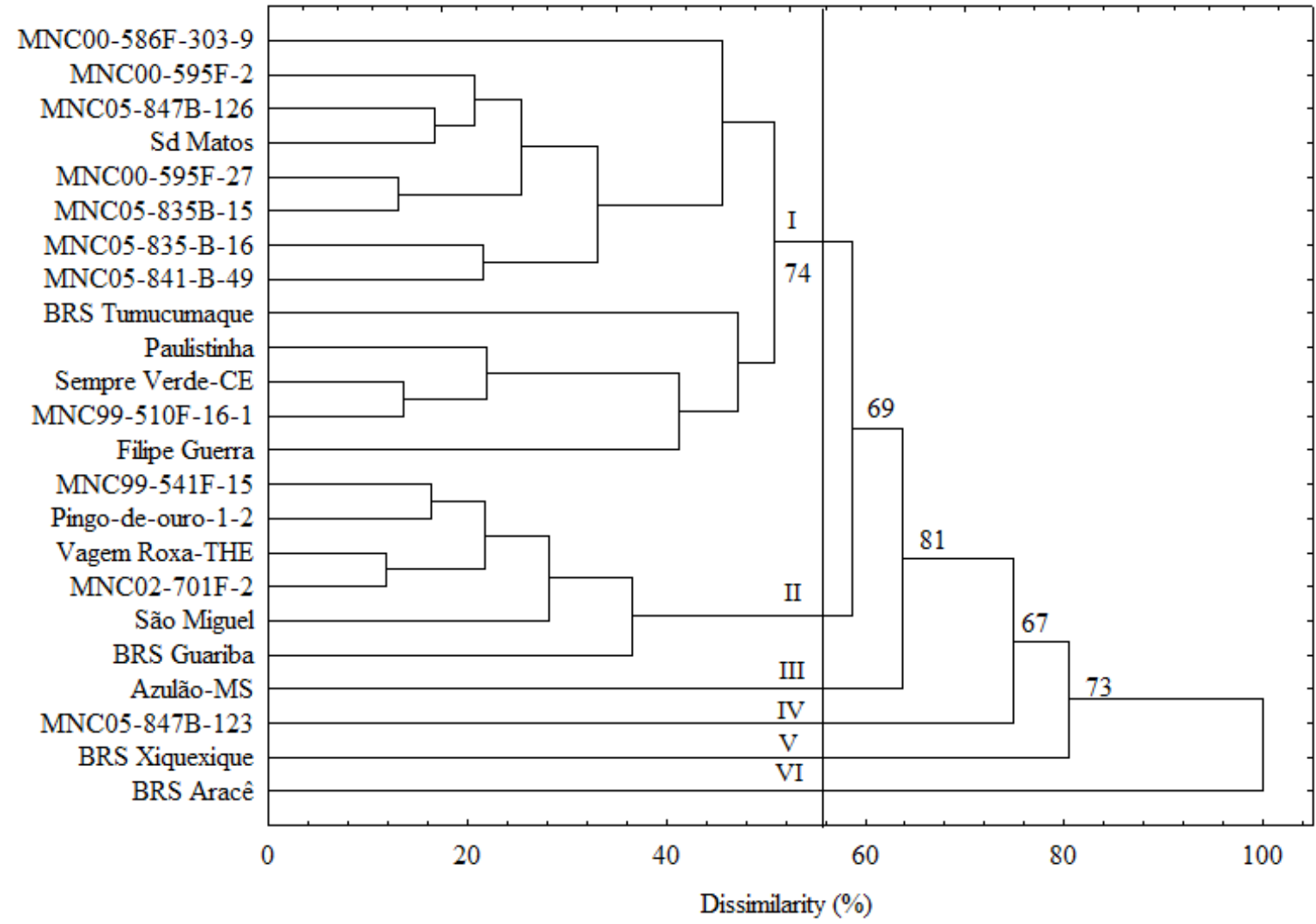

Figure 3. UPGMA grouping of cowpea genotypes evaluated in the joint analysis from the distances of Mahalanobis. (Cophenetic correlation $\mathrm{r}_{1}=0.79 * *, \mathrm{p}<0.01$ ). 
Table 2. Estimates of the correlation between dissimilarity matrices and consensus index between dendrograms constructed by the UPGMA method for grouping cowpea genotypes.

\begin{tabular}{ccc}
\hline Combination & $\begin{array}{c}\text { Correlation between dissimilarity } \\
\text { matrices }\end{array}$ & $\begin{array}{c}\text { Consensus index (\%) } \\
\text { between dendrograms }\end{array}$ \\
\hline Experiment 1 - Experiment 2 & $0.34^{*}$ & 27.13 \\
Experiment 1 - Combined & $0.83^{* *}$ & 64.32 \\
Experiment 2 - Combined & $0.52^{* *}$ & 41.26 \\
\hline
\end{tabular}

A possible explanation for differences observed in the groupings would be effects of $\mathrm{G} \times \mathrm{E}$ interaction. Although the presence of $\mathrm{G} \times \mathrm{E}$ interaction is well-recognized when evaluating several genotypes in at least two environments, there is little information about its influence in studies of divergence. Thus, joint analysis of deviance was performed to test the effect of $\mathrm{G} \times \mathrm{E}$ interaction on all characteristics that were evaluated. $G \times E$ interaction was found to be significant only for pod length, green grain yield, green pod yield, hydrogen-ionic potential, soluble solids, chlorophyll and total carotenoids (Table 3).

Table 3. Summary of the deviance analysis of 15 descriptors evaluated in 23 genotypes of cowpea in two experiments.

\begin{tabular}{|c|c|c|c|c|c|c|}
\hline \multirow[t]{2}{*}{ Descriptors } & \multicolumn{3}{|c|}{ Model (Deviance) } & \multirow[t]{2}{*}{$\mathrm{c}^{2}{ }_{(\mathrm{GE})}$} & \multirow[t]{2}{*}{$\mathrm{r}_{\text {gloc }}$} & \multirow[t]{2}{*}{$\mathrm{S}_{\mathrm{j}}(\%)$} \\
\hline & Complete & Genotype & $\mathrm{G} \times \mathrm{E}$ interaction & & & \\
\hline $\mathrm{NDF}$ & 530.98 & $532.4^{\mathrm{ns}}$ & $532.80^{\mathrm{ns}}$ & 0.11 & 0.48 & 1.10 \\
\hline PL & -2.69 & $-2.69^{\mathrm{ns}}$ & $-1.46^{\mathrm{ns}}$ & 0.08 & 0.60 & 0.50 \\
\hline NDM & 392.5 & $392.9^{\text {ns }}$ & $392.80^{\mathrm{ns}}$ & 0.02 & 0.70 & 0.70 \\
\hline $\mathrm{PH}$ & 119.8 & $120.2^{\mathrm{ns}}$ & $121.40^{\mathrm{ns}}$ & 0.10 & 0.43 & 0.50 \\
\hline LP & 356.2 & $356.2^{\mathrm{ns}}$ & $366.61^{*}$ & 0.26 & 0.02 & 3.10 \\
\hline NGP & 524.16 & $524.98^{\mathrm{ns}}$ & $524.16^{\mathrm{ns}}$ & 0.01 & 0.87 & 1.60 \\
\hline WP & 427.16 & $427.68^{\mathrm{ns}}$ & $428.78^{\mathrm{ns}}$ & 0.12 & 0.35 & 1.20 \\
\hline WG & 257.23 & $257.25^{\mathrm{ns}}$ & $259.67^{\mathrm{ns}}$ & 0.14 & 0.12 & 0.65 \\
\hline IGR & 1041.5 & $1043.00^{\mathrm{ns}}$ & $1041.60^{\mathrm{ns}}$ & 0.02 & 0.81 & 1.13 \\
\hline YGG & 2564.69 & $2564.70^{\mathrm{ns}}$ & $2602.19^{* *}$ & 0.51 & 0.02 & 27.98 \\
\hline YGV & 2737.55 & $2737.92^{\mathrm{ns}}$ & $2773.76^{* *}$ & 0.47 & 0.03 & 49.83 \\
\hline $\mathrm{pH}$ & -13.79 & $-13.78^{\mathrm{ns}}$ & $-18.78^{* *}$ & 0.73 & 0.01 & 4.60 \\
\hline SS & 1611.89 & $1611.90^{\mathrm{ns}}$ & $1617.63^{* *}$ & 0.25 & 0.04 & 1.80 \\
\hline $\mathrm{CHL}$ & -2036.91 & $-2033.19^{*}$ & $-2032.73^{* *}$ & 0.19 & 0.09 & 2.50 \\
\hline $\mathrm{TC}$ & -1943.46 & $-1940.66^{\mathrm{ns}}$ & $-1937.46^{* *}$ & 0.20 & 0.05 & 2.80 \\
\hline
\end{tabular}

**, *: significant at 1 and $5 \%$ by the Chi-square test; $\mathrm{c}^{2}{ }_{(\mathrm{GE})}$ : contribution of the interaction $\mathrm{G} \times \mathrm{E}$ to the phenotypic variance; $r_{\text {gloc }}$ : genetic correlation between all environments; $S_{j}(\%)$ : contribution to genetic divergence by Sing's criterion. NDF: number of days for flowering; PL: percentage of lodging; NDM: number of days for maturation; PH: plant height; LP: length of the pod; NGP: number of grains per pod; WP: weight of the pod; WG: weight of grains; IGG: index of green grains; YGG: yield of green grains; YGP: yield of green pods; $\mathrm{pH}$ : hydrogen-ionic potential; SS: soluble solids; CHL: chlorophyll, and TC: total carotenoids.

$\mathrm{G} \times \mathrm{E}$ interaction can have a significant impact on phenotypic manifestation, especially in quantitative characters (GAUCH et al., 2008). In the context of the mixed models, the component $\mathrm{c}^{2}{ }_{(\mathrm{GE})}$ quantifies how much of the phenotypic variance is explained by the variance component of $\mathrm{G} \times \mathrm{E}$ interaction. Characteristics which showed the greatest effect of $\mathrm{G} \times \mathrm{E}$ interaction on phenotypic variance were in order: potential hydrogen-ionic, green-grain yield and green pod yield (Table 3). Characteristics that were affected to a lesser extent were pod length, soluble solids, chlorophyll and total carotenoids.

The average genotypic correlation of the performance of the cultivars in the environments $\left(r_{\text {gloc }}\right)$, provides the reliability of how constant is the ordering of the cultivars, being, therefore, a meter of the complex interaction. Corroborating with estimates of the $c^{2}{ }_{(\mathrm{GA})}$ component, it was found that the characters in which the interaction was detected the $r_{\text {gloc }}$ estimation was reduced, whereas in the characters without the interaction the values were medium to high (between 0.35 and 0.81 ) (Table 3 ). In the context of the estimation of the genetic divergence between accesses of a germplasm bank, the quantification of the $r_{\text {gloc }}$ magnitude informs in which characteristics the complex component has more relevance and, consequently, more influences the ordering of the accesses that are being evaluated.

It is known that in some characteristics, especially those controlled by several genes of small effect and that undergo greater environmental influence (quantitative characteristics), such as productivity, $\mathrm{G} \times \mathrm{E}$ interaction of the complex type is more pronounced (NUNES et al., 2011). In this study, this was demonstrated in the characteristics of green grain yield and yield of green beans, which contributed most to genetic divergence according to 
Singh (1981) criterion (Table 3). These characteristics combined accounted for $77.81 \%$ of the genetic divergence, demonstrating the strong influence of $\mathrm{G} \times \mathrm{E}$ interaction in the different groupings observed in the two evaluations.

Considering that the presence of the interaction $\mathrm{G} \times \mathrm{E}$ affects the formation of the groups, from the results presented in Table 1, it is verified that the joint analysis is an alternative to reduce the effect of the interaction $\mathrm{G} \times \mathrm{E}$, since in the joint analysis it is possible to estimate its effect, which remains confused with the effect of genotypes when the analysis is performed in only one environment (SILVA et al., 2011).

Similarity between genotype grouping in individual analyses and joint analysis was observed, indicated by the correlation of distance matrices and the consensus index of the dendrograms, shown in Table 1. Therefore, the grouping in the joint analysis will allow the identification of possible crosses among genotypes for the generation of segregating populations with potential for selection in the subsequent stages of the breeding program.

In breeding programs, genetic divergence analysis aims to identify parents for the generation of populations with genetic variability and consequent genetic gain in successive selection cycles. In selecting the most divergent parents, it is advisable to select, within each group, parents with higher averages in relation to those characters to be improved, with the aim of achieving the maximum concentration of favorable alleles, according to the selection objectives.

Depending on the groups formed, it is possible to indicate some crosses considering the dissimilarity between the pairs of genotypes. The recommendation is that the crosses contemplate genotypes belonging to different groups. It should be noted that the genotypes BRS Aracê and BRS Xiquexique were the most divergent among the evaluated genotypes, the latter having the highest average for yield of green grains. Considering the eleven largest distances between pair of genotypes, the cultivar BRS Aracê (Group VI) is among six, including the four largest in the crosses with São Miguel, Vagem Roxa-THE, MNC02-701F-2 and BRS Guariba, all of them Group II (Figure 3). The cultivar BRS Xiquexique is among the three largest distances, with the genotypes MNC05-847B-123 (Group IV), Azulão-MS (Group III) and MNC00-586F-303-9 (Group I). Two other crosses recommended, based on genetic distance, involve the cultivar BRS Guariba (Group II) with Paulistinha (Group I) and MNC05-847B-123 (Group IV), totaling eleven crosses. It is anticipated that segregant populations with mean and high genetic variability for grain yield would be obtained from these crosses.

\section{CONCLUSION}

This study of genetic divergence demonstrated that interaction of genotype with the environment directly influences the contribution of characteristics and grouping of cowpea genotypes.

The genetic divergence of the set of cowpea genotypes studied here is mainly due to the yield of green beans and pods.

Cultivars BRS Aracê and BRS Xiquexique were the most divergent of the genotypes studied, representing $75 \%$ of the recommended crosses.

\section{ACKNOWLEDGEMENTS}

Special thanks are due to Embrapa Meio-Norte for supplying the genetic material used in this study, to Universidade Federal Rural do Semi-Árido for making the facilities available to conduct this research and to the Conselho Nacional de Pesquisa e Desenvolvimento Científico for the provision of a scholarship of scientific initiation.

\section{REFERENCES}

ALMEIDA, A. L. G. et al. Produtividade do feijãocaupi cv BR 17 Gurguéia inoculado com bactérias diazotróficas simbióticas no Piauí. Revista Brasileira de Ciências Agrárias, Recife, v. 5, n. 3, p. 364-369, 2010.

BARROS, M. A. et al. Adaptabilidade e estabilidade produtiva de feijão-caupi de porte semiprostrado. Pesquisa Agropecuária Brasileira, Brasília, v. 48, n. 4, p. 403-410, 2013.

CARMO FILHO, F.; ESPÍNOLA SOBRINHO, J.; MAIA NETO, J. M. Dados climatológicos de Mossoró: um município semi-árido nordestino. Mossoró, RN: ESAM, 1991. 121 p.

COSTA, E. M. et al. Nodulação e produtividade de Vigna unguiculata (L.) Walp. por cepas de rizóbio em Bom Jesus, PI. Revista Ciência Agronômica, Fortaleza, v. 42, n. 1, p. 1-7, 2011.

CRUZ, C. D.; CASTOLDI, F. L. Decomposição da interação genótipos $\mathrm{x}$ ambientes em partes simples e complexa. Revista Ceres, Viçosa, v. 38, n. 219, p. 422-430, 1991.

CRUZ, C. D. GENES - A software package for analysis in experimental statistics and quantitative genetics. Acta Scientiarum: Agronomy, Maringá, v. 35, n. 3, p. 271-276, 2013.

\section{EMPRESA BRASILEIRA DE PESQUISA}


AGROPECUÁRIA - EMBRAPA. Centro Nacional de Pesquisa de Solos. Sistema Brasileiro de Classificação de Solos. Rio de Janeiro, RJ: Embrapa Produção da Informação, 1999. 412 p.

FREIRE FILHO, F. R. Feijão-caupi: produção, melhoramento genético, avanços e desafios. Teresina, PI: Embrapa Meio-Norte, 2011. 84 p.

FREIRE FILHO, F. R. et al. Adaptabilidade e estabilidade da produtividade de grãos de genótipos de caupi enramador de tegumento mulato. Pesquisa Agropecuária Brasileira, Brasília, v. 38, n. 5, p. 591-598, 2003.

FREIRE FILHO, F. R. et al. Adaptabilidade e estabilidade produtiva de feijão-caupi. Ciência Rural, Santa Maria, v. 35, n. 1, p. 24-30, 2005.

GAUCH, H. G. et al. Statistical analysis of yield trials by AMMI and GGE: further considerations. Crop Science, Madison, v. 48, n. 3, p. 866-889, 2008.

MAHALANOBIS, P. C. On the generalized distance in statistics. Proceedings of the National Institute of Science of India, New Delhi, v. 12, n. 1, p. 49-55, 1936.

MIRANDA, G. V. et al. Potencial de melhoramento e divergência genética de genótipos de milho-pipoca. Pesquisa Agropecuária Brasileira, Brasília, v. 38, n. 6, p. 681-688, 2003.

MOJENA, R. Hierarchical grouping method and stopping rules: an evaluation. Computer Journal, Oxford, v. 20, n. 4, p. 359-363, 1977.

NUNES, G. H. S. et al. Phenotypic stability of hybrids of Galia melon in Rio Grande do Norte state, Brazil. Anais da Academia Brasileira de Ciências, Rio de Janeiro, v. 83, n. 12, p. 1421-1434, 2011.

RESENDE, M. D. V. Software SELEGEN-REML/ BLUP: sistema estatístico e seleção genética computadorizada via modelos lineares mistos. Colombo: Embrapa Florestas, 2007. 359 p.

ROCHA, M. M. et al. Adaptabilidade e estabilidade produtiva de genótipos de feijão-caupi de porte semi-ereto na Região Nordeste do Brasil. Pesquisa Agropecuária Brasileira, Brasília, v. 42, n. 9, p. 1283-1289, 2007

SANTOS, A. et al. Adaptabilidade e estabilidade de genótipos de feijão caupi ereto via REML/BLUP e GGE Biplot. Bragantia, Campinas, v. 75, n. 3, p. 299-306, 2016.
SANTOS, C. A. F. et al. Comportamento agronômico e qualidade culinária de feijão-caupi no Vale do São Francisco. Horticultura Brasileira, Brasília, v. 26, n. 3, p. 404-408, 2008.

SILVA, J. M. et al. Implicações da interação genótipos $\mathrm{x}$ ambientes por ganho de seleção em meloeiro. Ciência Rural, Santa Maria, v. 41, n. 1, p. 51-56, 2011.

SINGH, B. B. Recent progress in cowpea genetics and breeding. Acta Horticulturae, Leuven, v. 752, s/n., p. 69-75, 2007.

SINGH, D. The relative importance of characters affecting genetic divergence. Indian Journal of Genetic and Plant Breeding, New Delhi, v. 41, n. 2, p. 237-245, 1981 .

SOARES, A. L. L. et al. Eficiência agronômica de rizóbios selecionados e diversidade de populações nativas nodulíferas em Perdões (MG). I - caupi. Revista Brasileira de Ciência do Solo, Viçosa, v. 30, n. 5, p. 795-802, 2006.

SOKAL, R. R.; ROHLF, F. J. The comparison of dendrograms by objective methods. Taxon, Vienna, v. 11, n. 2 , p. $33-40,1962$.

TEODORO, P. E. et al. Redes neurais artificiais para identificar genótipos de feijão-caupi semiprostrado com alta adaptabilidade e estabilidade fenotípicas. Pesquisa Agropecuária Brasileira, Brasília, v. 50, n. 11, p. 1054-1060, 2015a.

TEODORO, P. E. et al. Redes neurais artificiais para identificar genótipos de feijão-caupi semiprostrado com alta adaptabilidade e estabilidade fenotípicas. Pesquisa Agropecuária Brasileira, Brasília, v. 50, n. 11, p. 1054-1060, 2015 b.

VALADARES, R. N. et al. Adaptabilidade e estabilidade fenotípica em genótipos de feijão-caupi (Vigna unguiculata (L.) Walp.) de porte ereto/semiereto nas mesorregiões Leste e Sul maranhense. Agropecuária Científica no Semi-Árido, Campina Grande, v. 6, n. 2, p. 21-27, 2010. 